\title{
Quasi-Telic Perfective Aspect in Dëne Sựiné (Chipewyan)
}

\author{
Andrea Wilhelm \\ The University of Calgary
}

Dëne Sưtiné (short: Dëne), a Northern Athapaskan language spoken in the Northwest of Canada, shows an unusual patterning of situation type, the lexical aspectual meaning of a verb (and its complements), and viewpoint aspect. The perfective, one of the two obligatory viewpoint aspects of Dëne, imposes situation-type telic meaning on predicates, thus obscuring the important theoretical distinction between viewpoint aspect and situation type aspect (Comrie 1976, Smith 1991).

This paper has two goals. First, it provides a detailed empirical description of the meaning of the Dëne perfective, showing that all perfective predicates entail event completion, i.e., act like telic (perfective) predicates. However, as I also show, perfective predicates can independently be established as telic or atelic. Thus, the Dëne perfective is "quasi-telic". The second goal is to provide a formal analysis of the quasi-telic meaning, an analysis which does not abandon the theoretical distinction between perfectivity and telicity, or viewpoint and situation aspect more generally. The analysis consists of two points: (i), the Dëne perfective does operate in the domain of viewpoint aspect and not of situation aspect; (ii), its quasi-telic meaning is the result of including a posttime of the event. I then show the significance of my findings for the debate whether Dëne and related languages have a grammatical telicity distinction. I claim that the quasi-telic meaning of the perfective allows the Dëne language not to grammaticize telicity. More generally, while viewpoint and situation type are different levels of aspectual meaning, they are nonetheless capable of fulfilling similar functions. Therefore, it is possible that only one of these two levels is active in a language's grammar. Dëne is a language in which only viewpoint aspect is active.

\section{Background: Perfective Viewpoint and Telic Situations}

I follow the common assumption (e.g., Klein 1994, Giorgi \& Pianesi 1997, Kratzer 1998, Demirdache \& Uribe-Etxebarria 2000) that viewpoint aspect relates two times, namely the Reichenbachian Reference Time (TR) and the Event or Situation Time (TSit). There are two basic relations, TR $\subseteq$ TSit and TSit $\subseteq \mathrm{TR}$, which correspond to imperfective and perfective viewpoint, respectively. TR $\subseteq$ TSit has the effect of looking "at the situation from the inside" (Comrie 1976:4), which is a common characterization of imperfective viewpoint. TSit $\subseteq$ TR has the effect of looking "at the situation from the outside" and presenting "the totality of the situation referred to"-typical of perfective viewpoints (Comrie 1976:3, 4).

Situation type aspect does not relate two times, but is a characterization of the situation denoted by a verb and its complements. Much of linguistic theory 
distinguishes four situation types: states, activities, accomplishments and achievements (e.g., Vendler 1967, Dowty 1979, Smith 1991). Of these, accomplishments and achievements are telic, denoting situations which have an inherent endpoint/change of state, e.g., English bake a cake. Activities and states are atelic, denoting situations without an inherent endpoint/change of state, such as English laugh or pray. Telic predicates are of ten characterized as having quantized reference, and atelic predicates as having cumulative reference, (e.g., Krifka 1992):

(1) telic predicate/quantized reference: $\forall \mathrm{e}, \mathrm{e}^{\prime}\left[\mathrm{P}(\mathrm{e}) \wedge \mathrm{P}\left(\mathrm{e}^{\prime}\right) \rightarrow \neg \mathrm{e}^{\prime} \sqsubset \mathrm{e}\right]$ an event of which $\mathrm{P}$ is true does not have proper parts of which $\mathrm{P}$ is true

atelic predicate/cumulative reference: $\forall \mathrm{e}, \mathrm{e}^{\prime}\left[\mathrm{P}(\mathrm{e}) \wedge \mathrm{P}\left(\mathrm{e}^{\prime}\right) \rightarrow \mathrm{P}\left(\mathrm{e} \sqcup \mathrm{e}^{\prime}\right)\right]$ if $\mathrm{P}$ is true of two events, it is also true of the join of these two events

As already stated above, situation type and viewpoint are considered independent aspectual levels. Thus, while viewpoints operate on situations, or rather, on the time of a situation, crucially they do not alter situation type (e.g., Comrie 1976, Smith 1991). For example, the distinction between telic and atelic predicates is usually maintained in perfective viewpoint (cf. Smith 1991), as shown by the "in/for an hour" test in (3). Moreover, telic perfective predicates, which contain an inherent endpoint/change of state, denote a situation which has been completed, (4). Atelic perfective predicates, which lack an inherent endpoint/change of state, denote a situation which has not been completed but has simply ended, (5).

a. She baked a cake (in one hour).

TELIC

b. She prayed (for one hour).

ATELIC

(5) She prayed this morning ( $\sqrt{\text { but }}$ she did not finish praying (the entire prayer)).

ATELIC

The fact that perfective viewpoints do not standardly entail event completion is emphasized in Comrie (1976:18f):

"the use of 'completed' [...] puts too much emphasis on the termination of a situation, whereas the use of the perfective puts no more emphasis, necessarily, on the end of a situation than on any other part of the situation, rather all parts of the situation are presented as a single whole. [...] Indicating the end of a situation is at best only one of the possible meanings of a perfective form, certainly not its defining feature."

\section{Description of the Dëne Perfective}

We shall now begin to see that the Dëne perfective is an exception to this characterization, in that it always denotes a completed event. Dëne is a head- 
marking, polysynthetic SOV language. There is no inflection for tense; postverbal "particles" indicate a range of meanings from negation and mood to tense-like meanings. Verbs in realis clauses are obligatorily inflected for perfective or imperfective viewpoint aspect. These two viewpoints are quite uncontroversial in the Athapaskan literature. Instead, there is a debate on situation type, and in particular on whether Athapaskan languages have a grammatical distinction between telic and atelic predicates (Smith 1991, 1996, Midgette 1996, Bortolin 1998, Rice 2000). While I am not directly concerned with this debate here, I want to emphasize that viewpoint aspect also needs to be examined in the telicity debate, since, as I claim, what the grammar of a language does at one aspectual level influences what it does at other aspectual levels. In Dëne the perfective viewpoint, which covers many of the functions of telicity, provides a motivation for the view that telicity is not grammaticized in this language.

Turning now to the form of the Dëne perfective, it is signalled by a prefix and/or a stem change. ${ }^{2}$ The prefixes, ghe-, the-, or $n e-$, are located in the inflectional domain of the verb (cf. Rice 2000). The imperfective (in nonstative verbs; see section 6 for stative verbs) is signalled by the absence of a perfective prefix (shown as $\varnothing$ below) and/or by the imperfective (i.e., unchanged) stem. Viewpoint prefixes are underlined in all examples. ${ }^{3}$

a. hesbes

IMPF

he- $\underline{\varnothing-s-t-b e s}$

ep-impf-1s-cl-boil

'I am boiling it (e.g., meat)'

b. thitbes

PERF

the-i-t-bes

perf-1s-cl-boil

'I boiled it'

a. yasti

ya- $\underline{\varnothing-s-t-t i}$

IMPF

th-impf-1s-cl-(talk/pray)

'I am talking/praying'

b. yaghitti

PERF

ya-ghe-i- $t-t i$

th-perf-1s-cl-(talk/pray)

'I talked/prayed'

a. Tuneshe

IMPF

?u-ne- $\underline{\varnothing}-s-y e$

?-gd-impf-ls-pick (berries) impf

'I am picking berries'

b. Tuneghiya

?u-ne-ghe-i-yq

?-gd-perf-1s-pick (berries) perf

'I picked berries' 
Let us now turn to the meaning of the Dëne perfective. The first indication of its completive meaning comes from comparing Dëne sentences with past time reference: Perfective forms suggest that the event has been completed, while imperfective forms do not (and therefore require some context).

a. Tịtá néné k'étt'á yoh hottsi ni ni IMPF ?ịtá néné k'étt'á yoh ho-Øַ-t-tsi ni one year duration.of house gd-impf-cl-make sgO past 's/he was making a/the house for a year' implied: the house is not finished

b. Jịtá néné k'étt'á yoh hóttsị nị PERF Jịá néné k'étt'á yoh ho-the-t-tsi ni one year duration.of house gd-perf-cl-make sgO past 's/he built a/the house for a year/over a year' implied: the house is finished
a. thidziné k'e jis nánathiłdá tthidziné $k$ 'e jis ná-na-the-i-t-dá yesterday mitt ?- ?- perf-1s-cl-(patch) past 'yesterday I patched the mitt' implied: I am finished/the mitt is patched
b. thidziné k'e jis nánasdą nị... thidziné k'e jis ná-na-吕- s-t-dạ nị 'yesterday I was patching the mitt (when...), yesterday I patched the mitt for a while (when...)' implied: I am not finished/the mitt is not patched yesterday mitt ?- ?- impf-1s-cl-(patch) past IMPF

Next, it is instructive to look at spontaneous translations into English of perfective Dëne sentences: They often contain an extra English expression like finish which indicates event completion-as if consultants did not find the English simple past sufficient for expressing the meaning of Dëne perfective predicates.

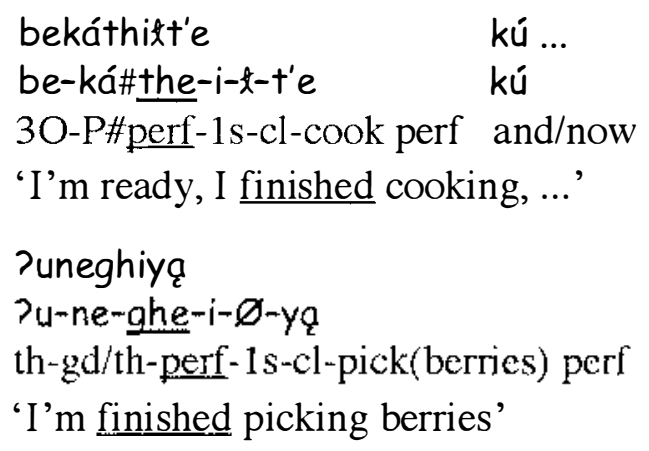

\section{?uneghiya}

?u-ne-ghe-i- $\varnothing-y q$

th-gd/th-perf-1s-cl-pick(berries) perf

'I'm finished picking berries' 
Finally, perfective verbs cannot be combined with ?anat'e 'stop/finish' because this represents a tautology, (13). Speakers would even comment that ?anat' $e$ is unnecessary and should be omitted in a perfective context. The fact that imperfective verbs are fine with Janat'e, (14), demonstrates that the constraint cannot be syntactic, but must be semantic.

perfective: tautology
a. \#/* nánathiłdą
Panast'e
ná-na\#the-i-t-dá
?a-na\#s-Ø-t'e
th-th\#perf-1s-cl-(patch)
th-th\#1s-cl-stem
b. \#/* yoh thittsi
yoh the-i-t-tsi
?anast'e
?a-na\#s- $\varnothing-t^{\prime} e$
house perf-1s-cl-make sgO th-th\#1s-cl-stem
c. \#/* yaghitti Tanast'e
ya\#ghe-i-t-ti गa-na\#s- $\varnothing-t^{\prime} e$
th-perf-1s-cl-(talk/pray) th-th\#1s-cl-stem

(14)

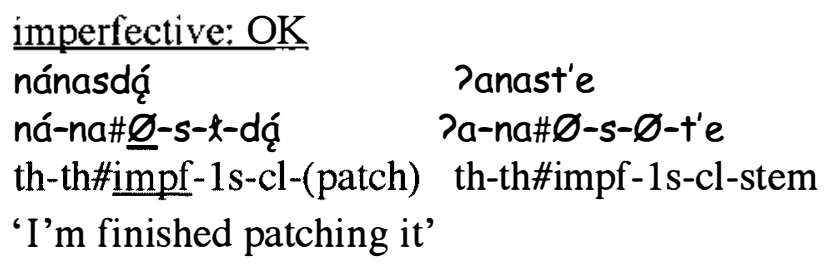

In sum, then, Dëne perfective predicates denote completed situations. Now, one may wonder what is so special about this. After all, English simple past sentences also usually denote a completed situation. However, as shown in (5) above, this completion meaning is cancellable with atelic predicates, and therefore in English is an implicature only. But crucially, in Dëne, the completion reading is never cancellable; it is entailed by the perfective irrespective of situation type. This is shown in the next section.

\section{Perfective entails event completion, irrespective of situation type}

According to Grice (1975) and Levinson (1984), a distinction has to be made in the meaning of an utterance between those elements which are truly entailed, and those which are an implicature only. Implicatures arise due to pragmatic principles, and, unlike entailments, can be cancelled through a subsequent utterance which denies the implicature. I used two clauses in attempting to cancel the completion meaning of the Dëne perfective: (i), 'but I did not finish V-ing', and (ii), 'and I'm still V-ing'. Both of them resulted in contradictions rather than cancellations, irrespective of situation type. Let us begin with implicature test (i).

The following two Dëne clauses best correspond to 'but I did not finish Ving'. (15a) is more general, but (15b) is preferred after transitive clauses. 
(15) meaning: 'but I'm not finished (it)' / 'but I didn't finish (it/V-ing)'
a. kúlú Panast'e-íle $\quad(<$ híle $)$
but 1s.finish-not
b. kúlú Janasdhën-ile (<híle)
but 1 s.finish $O$ perf-not

As is also the case in English, using one of these clauses after a telic (or semelfactive) predicate/sentence results in a contradiction, (16)-(18). However, unlike in English, a contradiction also arises when combining 'but I did not finish (it)' with an atelic (activity) predicate/sentence, (19). (No gloss is given for the cancellation clause.)

(16) accomplishments (telic)
a. tthidziné k'e bér thitbes
\# kúlú ?anasdhën-íle
tthidziné k'e bér the-i-t-bes
yesterday meat perf-1s-cl-boil
('yesterday I boiled some meat [but I'm not finished it]')
b. ts'ëre nánathiłdạ \# kúlú ?anasdhën-íle
ts'ëre ná-na\#the-i-t-dá
blanket th-th\#perf-1s-cl-(patch)
('I mended the/a blanket [but I'm not finished it]')

(17) achievement (telic)
Tsádhekụe níniya
\# kúlú Panast'e-íle
Tsádhekụe ní\#ne-i- $\varnothing-y a$
Edmonton adv/th\#perf-1s-cl-sg go perf
('I arrived in Edmonton [but I didn't finish (arriving)]')

(18) (semelfactive: not telic, but punctual)

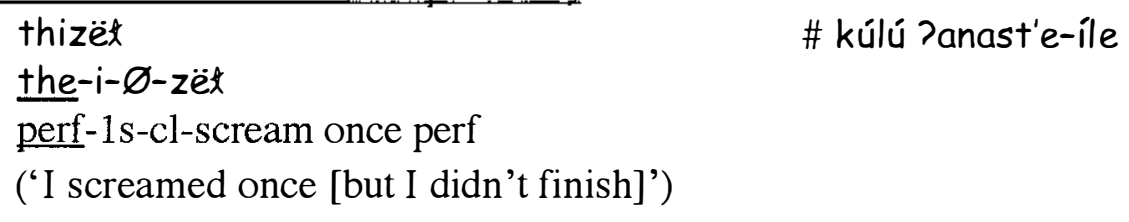

perf-1s-cl-scream once perf

('I screamed once [but I didn't finish]')

(19) activities (atelic)
a. yaghitti
\# kúlú Panast'e-íle
yaltghe-i- $-t-t i$
th\#perf-1s-cl-(talk/pray)
('I talked/prayed [but I didn't finish]')
b. bér ghit'adh
bér ghe-i- $\varnothing-t^{\prime} a d h$
\# kúlú Panasdhën-íle
meat perf-1s-cl-cut perf
('I cut (the) meat [but I'm not finished it]') 
These examples suggest that the completion reading is part of the (entailed) meaning of the perfective, rather than arising from the combination of perfective meaning and telic situations. This is confirmed by the second cancellation test, 'and I'm still V-ing', to which I turn now.

Again, since an event completion entailment is thought to result from the combination of telicity and perfectivity, 'and I'm still V-ing' is predicted to result in a contradiction only with telic predicates, but not with atelic ones. This is indeed the case in English, (20), and also in Navajo, a distantly related Athapaskan language, (21).

a. \# I baked a cake (this morning), and I'm still baking it. TELIC

b. $\sqrt{ }$ I prayed (this morning), and I'm still praying. ATELIC

(21) Navajo (Midgette 1996:317)

a. Kintahgóo bichidí yiníłbạááz

TELIC town-to his-car he-drove-it

**áádóo t’ahdii ńléígóó yoołbąs and still there-toward he-is-driving-it-along

'he drove his car to town **and he's still driving it there'

b. Awéé' yícha áádóó t'ahdii yicha sha'shin

ATELIC 'The baby cried and I guess s/he's still crying.'

In Dëne, however, a contradiction results not only with telic, but also with atelic (activity) situations, as demonstrated in (22) and (23). In fact, 'still V-ing' is only possible with atelic (or telic) situations on an interruption reading. Thus, in (24), there must have been a time preceding the reference time of the 'still crying' clause where 's/he' was not crying.

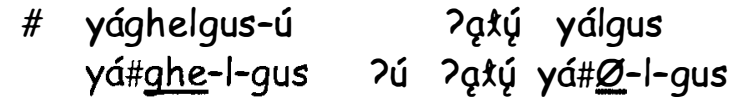

$$
\begin{aligned}
& \text { th\#perf-cl-jump and still th\#impf-cl-jump }
\end{aligned}
$$

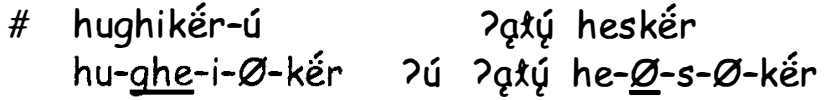

$$
\begin{aligned}
& \text { ser-perf-1s-cl-pat and still ep-impf-1s-cl-pat }
\end{aligned}
$$

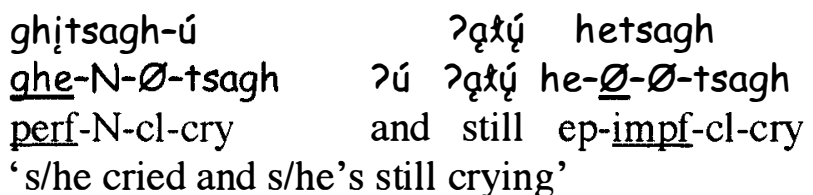

$$
\begin{aligned}
& \text { (after an interruption, s/he is crying again) }
\end{aligned}
$$

Summing up, then, the data in this section have shown that the completion reading of the Dëne perfective cannot be cancelled at all. This means that the Dëne perfective always entails event completion-irrespective of situation type. As already stated earlier, this raises problems for theories of aspect. First, 
standard accounts do not consider event completion an intrinsic part of perfective meaning; it is rather thought to result from the interaction of perfectivity and telicity. Thus, event completion is only predicted for telic perfective predicates, and the completion entailment seen in Dëne atelic perfective predicates remains unexplained. Second, the completive meaning of the Dëne perfective challenges the view that situation type and viewpoint are separate levels of aspect. This challenge arises because in terms of the completion reading, all Dëne perfective predicates act like telic predicates, and it seems as if the Dëne perfective viewpoint imparts telic situation type-a theoretically undesired mixing of these two levels. In the next section, I begin to account for the unusual constellation of viewpoint and situation type aspect in Dëne, by showing that situation type is independent of perfective viewpoint.

\section{Telic meaning in Dëne}

I now present evidence that telic meaning is independent of perfectivity in Dëne. In other words, I show that it is not the case that Dëne verbs are lexically unspecified for telicity and receive telic meaning only from the perfective. To do so, I use a common telicity test: the interpretation of 'almost' (Dowty 1979). With atelic predicates, 'almost' has an event onset reading only, (25), while telic accomplishments have an onset and a completion reading, (26).

(25) She almost laughed. (activity/atelic)

(i) $\checkmark$ She never laughed/never even started laughing. (ONSET)

(ii) \# She started laughing but did not finish laughing. (COMPL.)

(26) She almost wrote a letter. (accomplishment/telic)

(i) $\checkmark$ She never wrote the letter/never even started writing it. (ONSET)

(ii) $\checkmark$ She started writing the letter but did not finish it. (COMPL.)

In Dëne, this test clearly distinguishes between activities and accomplishments. Activities have an onset reading only, (27), and with accomplishments, the event completion reading is salient, (28).
a. k'ájëne ghitsagh
k'ájëne ghe-i- Ø-tsagh
almost perf-1s-cl-cry
'I almost cried (never started)'
b. ?k'ájëne ghesjën
k'ájëne ghe-s-d-shën
almost perf-1s-cl-sing
'I just about sang (but didn't)' (pragmatically a bit odd) 
c. k'ájëne yághesgus

k'ájëne yá-ghe-s-l-gus

almost th-perf-1s-cl-jump(cont)

'I almost jumped (continuously) (but didn't)'

d. k'ájëne yaghitti

k'ájëne ya-ghe-i-t-ti

si

almost th-perf-1s-cl-talk/pray assert

'I was going to speak but I didn't (I didn't get a chance to make my

(28)

a. k'ájëne bër thiłbes

speech)'

k'ájëne bër the-i-t-bes

almost meat perf-1s-cl-boil

'I'm almost done cooking the meat by boiling it,

I'm almost finished boiling the meat'

b. k'ájëne bekáthitt'e

k'ájëne be-ká\#the-i-t-t'e

almost 30-P\#perf-1s-cl-cook perf

'I'm just about finished cooking'

c. k'ájëne thittsị

k'ájëne the-i-t-tsi

almost perf-1s-cl-make $\mathrm{O}$

'I just about finished making it, I'm almost done making it'

d. k'ájëne nánathiłdą

k'ájëne ná-na-the-i-t-dá

almost ?-?-perf-1s-cl-(patch)

'I just about mended it' (event completion reading)

The clear difference in the interpretation of 'almost' shows that Dëne perfective predicates can be telic/accomplishments or atelic/activities. In other words, Dëne verbs must be specified for telicity independent of the perfective. This, in turn, means that the perfective morphemes are not telicity markers. Perfective verbs only "resemble" telic predicates in always entailing event completion, but this completion meaning must be derived in some other way. In the next section, I propose a perfective viewpoint semantics which derives the completion entailment, without making reference to or altering situation type/telicity. 


\section{Analysis: Dëne Perfective includes a Posttime}

\subsection{The Posttime Analysis}

Before making my proposal, let us review the semantics for a standard perfective viewpoint, namely TSit $\subseteq$ TR, illustrated in (29), and its interaction with telicity. I assume that TSit is a temporal trace function that converts e into a time (cf. Krifka 1992).

standard perfective:

$\exists \mathrm{e}[\mathrm{P}(\mathrm{e}) \wedge \mathrm{TSit}(\mathrm{e}) \subseteq \mathrm{TR}]$

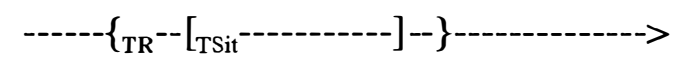

(based on Kratzer 1998)

Thus, the perfective says that there is a situation/an event e of which $\mathrm{P}$ is true, and the time of e (TSit(e)) is included in the reference time (TR).

As discussed in section 1, telic predicates, such as [VP John bake a cake], have quantized reference, i.e., if the predicate $\mathrm{P}$ is true of an event, then $\mathrm{P}$ cannot be true of any proper subevent of that event. Therefore, if (29) is true, there

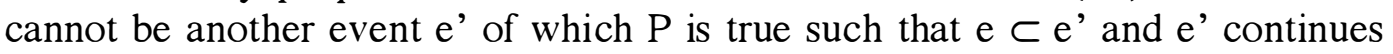
after the end of TR-put less formally, the "P-event" is finished. It is thus the quantization property of telic predicates which gives rise to the completion entailment in perfective viewpoint.

Since atelic predicates, such as $\left[_{V P} J o h n\right.$ pray], do not have quantized but cumulative reference (and therefore if $\mathrm{P}$ is true of an event, it may also be true of proper subevents), no completion entailment arises: There may be a P-event e' that includes e and that continues after the end of TR.

Clearly, we need a different definition for the Dëne perfective, one in which entailed event completion is not dependent on telicity/quantization. I propose that in the Dëne perfective, TR includes not only TSit, but also a posttime (TPost) of the situation. TPost is a "time after TSit" (Klein 1994:109, see also Parsons 1990:235).

$$
\begin{aligned}
& \text { Dëne perfective: } \quad \text {------\{ }\left\{\mathrm{TR}_{\mathrm{TR}}\left[\mathrm{TSit}^{---------]}\left[\mathrm{TPost}^{---}\right]\right\}-------->\right. \\
& \exists \mathrm{e}[\mathrm{P}(\mathrm{e}) \wedge \mathrm{TSit}(\mathrm{e}) \subseteq \mathrm{TR} \wedge \exists \mathrm{T}[\mathrm{T} \subseteq \mathrm{TR} \wedge \mathrm{TSit}(\mathrm{e})<\mathrm{T} \\
& \left.\left.\wedge \neg \exists e^{\prime}\left[P\left(e^{\prime}\right) \wedge T \cap \operatorname{TSit}\left(e^{\prime}\right) \neq \varnothing\right]\right]\right]
\end{aligned}
$$

(30') There is an event e whose run time is included in the reference time, and there is a time interval $\mathrm{T}$ (a posttime) which is also included in TR and: $\mathrm{T}$ follows the time of $\mathrm{e}$, and $\mathrm{T}$ does not overlap with the time of any event of which $\mathrm{P}$ is true.

For telic/quantized predicates, this definition has the same effect as the standard perfective, namely a completion entailment. However, a crucial difference arises with atelic/cumulative predicates: Since during a posttime, no events of which P is true can take place, the "entire" situation is over in TPost. TR therefore contains information that he situation is completely over. I propose that 
this is how a completion entailment is obtained. Since the completion entailment is due to the posttime, it obtains irrespective of situation type, which is the desired effect.

Let's illustrate this with an example. (32) shows the result of applying the perfective to the atelic predicate 'talk/pray' in Dëne.

$$
\begin{aligned}
& \begin{array}{l}
\text { John yaghitti ni } \\
\text { John perf-3s-talk/pray past }
\end{array} \\
& \text { 'John prayed.' } \\
& \exists \mathrm{e}[\operatorname{pray}(\mathrm{e}) \wedge \text { agent }(\mathrm{e}, \mathrm{John}) \wedge \mathrm{TSit}(\mathrm{e}) \subseteq \mathrm{TR} \wedge \exists \mathrm{T}[\mathrm{T} \subseteq \mathrm{TR} \wedge \mathrm{TSit}(\mathrm{e})<\mathrm{T} \\
& \left.\left.\wedge \neg \exists \mathrm{e}^{\prime}\left[\operatorname{pray}\left(\mathrm{e}^{\prime}\right) \wedge \operatorname{agent}\left(\mathrm{e}^{\prime}, \mathrm{John}\right) \wedge \mathrm{T} \cap \mathrm{TSit}\left(\mathrm{e}^{\prime}\right) \neq \varnothing\right]\right]\right]
\end{aligned}
$$

PERF

Although the verb ya-t-ti has cumulative reference, and thus may be true of a praying/talking event e which is a proper part of another praying/talking event e', the posttime under discussion must be a time after the ending of the "maximal" praying/talking event ( $e^{\prime}$ in (33)) of which $\mathrm{e}$ is a part. This is so because of the non-overlap condition on posttimes. ${ }^{4}$

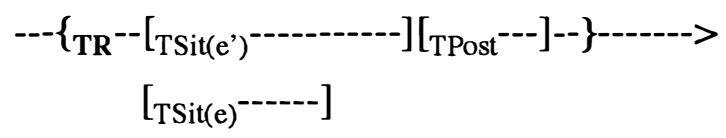

Due to the fact that a posttime starts only after the maximal praying/talking event has ended, perfective 'pray/talk' behaves like quantized predicates to which the standard perfective (as in (29)) is applied: The event of John praying/talking cannot continue after the end of TR, which gives rise to the entailment that the event is completed. This is highly likely to be the cause of the 'finish' meaning of the Dëne perfective (but see section 5.2).

Thus, the inclusion of a posttime is successful in deriving the quasi-telic (or quasi-quantized) meaning of the Dëne perfective. With the semantics given in (30), the Dëne perfective will entail that the "maximal" event of which the predicate is true is over, and thus entails event completion, irrespective of situation type. Crucially, however, this is achieved without manipulating the situation type of the predicate, i.e., (30) does not alter a predicate per se from cumulative to quantized: the event of which $\mathrm{P}$ is true may still have proper parts of which $\mathrm{P}$ is also true. All that (30) requires is that a posttime follow the maximal P-event. But this indirectly forces the TR of the perfective to include the maximal P-event.

In sum, the posttime analysis achieves precisely the characteristics found in the empirical description of the Dëne perfective given above, and it does so without breaking down the theoretical distinction between situation type and viewpoint aspect. 


\subsection{A "perfective paradox"?}

Now, one may ask why it is necessarily a 'finish' meaning, rather than for example a 'stop' meaning, that results from defining TPost such that it must follow the maximal P-event. For example, if ya- $t-t i$ 'talk/pray' is cumulative, the posttime may follow a (maximal) talking/praying event which may have simply been ended or interrupted, rather than finished or completed. Therefore, 'I prayed but I didn't finish' should be acceptable in at least some circumstances. ${ }^{6}$ However, as the data above showed, this is not the case (cf. (19a) for ya-t-ti 'pray/talk'). In other words, how does (30) explain that consultants reject "but I didn't finish (it)" with atelic perfective clauses?

This problem is in fact part of the larger issue of the relative division of labour of situation type and viewpoint aspect. For example, in English, there is a question of how the progressive of telic/quantized predicates (which are inherently completed) is able to not entail event completion, without changing the predicate type to atelic/cumulative. For example, a part of a baking-a-cake-event is not a baking-a-cake-event. How then is it that Sue was baking a cake entails that Sue was engaged in a baking-a-cake event but does not entail that she baked a cake (cf. Dowty 1979:133)? In other words, how does the progressive "get rid of" the completion inherent in telic predicates? The Dëne "perfective paradox" (where the problem is how to "get rid of" the incompletion inherent in atelic predicates) is the flip side of this English "imperfective paradox". A solution to the Dëne paradox could follow the spirit of the solutions proposed for English. For example, one could build the notion of event completion in the sense of 'finish' into the definition of the Dëne perfective (as, e.g., in the way that Parsons (1990) builds incompletion into the meaning of the English progressive), or one could develop a modal definition of the Dëne perfective along the lines of Dowty's (1979) and Landman's (1992) treatments of the English progressive. ${ }^{7}$

What both the English imperfective paradox and the Dëne perfective paradox suggest is that event (in)completion may be a viewpoint aspect notion after all, in spite of widely held assumptions to the contrary (as in Comrie 1976, Smith 1991). I leave this issue for further research.

\section{Evidence for the Posttime: Stative Verbs}

Independent evidence for the posttime analysis of the Dëne perfective comes from the behaviour of positional stative verbs in the language. Positional stative verbs come in pairs with eventive verbs, for example, 'sit' and 'sit down'. Interestingly, the imperfective positional statives are really perfectives (cf. Li 1946, Kari 1979), morphologically and semantically.

Let us first look at the morphology. The imperfective stem of a positional stative is identical with the perfective stem of the corresponding eventive verb. Thus, both imperfective 'sit' and perfective 'sit down' have the low-toned stems $-d a,-k e,-t+h ' i$ (for sg, dual and pl subjects, respectively): 
(34) positional stative verbs 'sit'
a. imperfective stems: $-d a,-k e,-t+h ' i$
(sg, dual \& pl stems)
b. perfective stems: -dá,-ké,-tth'í
(sg, dual \& pl stems)

(35) achievement verbs 'sit down'
a. perfective stems: $-d a,-k e,-t+h ' i$
(sg, dual \& pl stems)

b. imperfective stems: - dá, -kí, -tth'í

(sg, dual \& pl stems)

Moreover, imperfective positional statives have a perfective inflectional paradigm. Unlike in eventive verbs and many other stative verbs, the imperfective viewpoint prefix is not $\varnothing$, but the-, and the 1 sg subject marker is $i$ - rather than $s$ This is precisely the inflectional paradigm that a large class of eventive verbs shows in the perfective. ${ }^{8}$ Compare (36) with (37) and (38):

imperfective 'sit' (stative)
\begin{tabular}{|l|l|l|l|}
\hline a. & thida & the-i- $\varnothing$-da & viewpt-1s-cl-stem \\
\hline b. & thiida & the-ne- $\varnothing$-da & viewpt-2s-cl-stem \\
\hline c. & theda & the- $\varnothing-\varnothing$-da & viewpt-3s-cl-stem \\
\hline
\end{tabular}

pcrfective 'boil' (eventivc)
\begin{tabular}{|l|l|l|l|}
\hline a. & thiłbes & the-i-t-bes & vicwpt-1s-cl-stcm \\
\hline b. & thįłbes & the-ne-t-bes & viewpt-2s-cl-stem \\
\hline c. & yétbes & ye-H(<the $)-\varnothing$-t-bes ${ }^{9}$ & 4O-viewpt-3s-cl-stem \\
\hline
\end{tabular}

cf. imperfective 'boil' (eventive)
\begin{tabular}{|l|l|l|l|}
\hline a. & hesbes & he- $\underline{\varnothing}-\underline{-}$-t-bes & ep-viewpt-1sg-cl-stem \\
\hline b. & netbes & $\underline{\varnothing}$-ne-t-bes & vicwpt-2s-cl-stem \\
\hline c. & yetbes & ye- $\underline{\varnothing}$ - $\varnothing$-t-bes & 40-viewpt-3s-cl-stem \\
\hline
\end{tabular}

Semantically, imperfective positional statives are also perfectives. They denote the result state of a sitting-down event. For example, (36a) means 'I am sitting', but consultants will elaborate that it means 'I sat down and am now sitting'. It is thus very likely that Dëne imperfective positional statives are derived from eventive perfective verbs. This pattern falls out naturally from the posttime analysis. We can simply assume that, by "foregrounding" the posttime, these verbs come to denote the result state that obtains during the posttime.

The posttime analysis finds even stronger support from perfective positional stative verbs. These are morphological perfectives, i.e., "perfectives of perfectives", as shown in (39): They take the viewpoint prefix ghe-, which is found with another large class of perfective eventive verbs (cf. (7b), (8b) above) and which, according to Kari (1979), may be the default perfective prefix: 


pcrfective 'sit' (stative)
\begin{tabular}{|l|l|l|l|}
\hline a. & ghidá & ghe-i- $\varnothing$-dá & viewpt-1s-cl-stem \\
\hline b. & ghịdá & ghe-ne- $\varnothing$-dá & viewpl-2s-cl-stem \\
\hline c. & ghịdá & ghe-N- $\varnothing$-dá & viewpt-3s-cl-stcm \\
\hline
\end{tabular}

More importantly, the meaning of perfective statives clearly shows the presence of a posttime. Thus, (39a) means 'I sat (now I don't anymore)', i.e., the state of sitting must be over. This is clearly different from a more standard perfective meaning, as illustrated with English in (40), and is accounted for by the posttime analysis proposed above.

(40) (10 minutes ago,) he sat on the front steps, and (now) he's still sitting there.

Summing up to this point, eventive and even more so positional stative verbs provide evidence that the Dëne perfective differs in meaning from more standard perfective viewpoints. The Dëne perfective places strong emphasis on event completion, and entails that the situation cannot continue (without interruption) after TR. Unlike in English, this is so even for atelic predicates. To account for these facts, I proposed that the Dëne perfective, unlike most perfectives, includes a posttime which must not overlap with the (time of) an event of which the predicate is true.

To conclude this paper, I turn to the significance of the Dëne perfective for theories of aspect in Athapaskan languages and in general.

\section{Shared functions of viewpoint and situation aspect}

If one looks more closely at the situation type facts in Dëne, one realizes that the unusual, quasi-telic meaning of the perfective in this language is no accident. In Dëne and other Athapaskan languages, the status of telicity is under debate, and I argue in related work (Wilhelm 2002, in prep.) that telicity is not grammaticized in Dëne. In other words, Dëne predicates can have telic meaning, but telicity has no grammatical or morphosyntactic correlates. For example, there is no verb morphology which reflects telicity. Moreover, nominal properties such as count/mass/quantization are not marked overtly, e.g., (41), and do not influence interpretation as telic or atelic.

(41) tue thetbes

fish perf-3s-boil 's/he boiled fish meat/ a fish/ the fish/ some/several fish'

Thus, telicity as a situation type does not play a large role in Dëne. Instead, the perfective viewpoint has quasi-telic meaning. I argue that in Dëne, viewpoint aspect is the aspectual level "active" in the grammar, and that the meaning of one of the viewpoints, the perfective, "compensates" for the inactivity of telic situation type. We thus see that the examination of viewpoint sheds new 
light on the debate on telicity in Dëne/Athapaskan, providing a motivation for the view that telicity is not grammaticized. ${ }^{10}$

More generally, I propose that there exists a close relationship between situation type and viewpoint aspect, in that they share important discourse-related functions. For example, both perfective viewpoint and telic situation type have the capability of specifying the temporal relationship between situations in a discourse as sequential (e.g., Comrie 1976, Hopper 1982, Kamp \& Rohrer 1983, Partee 1984, Dahl 1985, ter Meulen 1995). ${ }^{11}$

This view is supported by an examination of a language in which viewpoint aspect is not active. South German is such a language (or group of dialects); it has no grammaticized viewpoint distinctions. The simple present tense is used for all present and future time reference, and the present perfect is used for all past time reference (the double perfect expresses past perfect meanings), irrespective of viewpoint aspect (e.g., Paul 1959, Kratzer 1998). Interestingly, it has been suggested that in German, it is telic situation type which specifies a sequential relationship between situations, i.e., which has "default" perfective meaning (Bohnemeyer \& Swift 2001), and, crucially, telicity is grammaticized pervasively in this language. Among other things, object properties such as count/mass/quantization are marked overtly and influence the interpretation of a predicate as telic or atelic (e.g., Krifka 1992), and certain particles derive telic verbs, e.g., arbeiten 'work' (atelic) but abarbeiten 'work off (e.g., a debt)' (telic). In South German, then, in the absence of viewpoint aspect, situation type is the "active" aspectual level.

The comparison of Dëne and South German suggests that both perfectivity and telicity can bound an event in discourse, and that the grammatization of this function on both aspectual levels (telic situations and perfective viewpoint) is unnecessary. In Dëne, we see an event bounding strategy which has the grammatical characteristics of a viewpoint aspect. However, due to the absence of telicity in Dëne, this viewpoint has a more restrictive meaning than standard perfectives: it entails event completion. While this resembles telic meaning, the Dëne perfective is nonetheless accounted for in a manner typical of viewpoint aspects, namely by relating TSit and TR. The quasi-telic meaning is accounted for by including a posttime in TR.

In conclusion, the analysis presented in this paper accounts for the similarities between perfectivity and telicity, without abandoning the theoretical distinction between viewpoint and situation aspect.

\section{Endnotes}

*I am very grateful to Shirley Cardinal, Ernest Ennow, John Janvier, Nora Matchatis, and Valerie Wood for sharing their language expertise with me. Special thanks are due to Sally Rice and all members of the Daghida Project for their generous cooperation, and to Cold Lake First Nations for permitting me to 
conduct fieldwork among them. Please note that I am not representing phonological and lexical variation among speakers.

This research has benefited from discussion with Ed Cook, Manfred Krifka, Amanda Pounder, Keren Rice, and especially Betsy Ritter and Hotze Rullmann. Thanks are also due to the audiences of SALT 13, of the 2002 Workshop on Complex Predicates, Particles and Subevents (Konstanz), WSCLA 2002 (Edmonton) and the ZAS-Semantikzirkel (Berlin) for helpful feedback. All errors etc. are my own. Funding was provided by SSHRC Doctoral Fellowship No. 75299-1946, University of Calgary Thesis Research Grant No. 994409, and a California Indian Language Center Grant.

1 Smith (1991) distinguishes a fifth situation type, semelfactive, which characterizes atelic nondurative situations, such as tap or knock.

${ }^{2}$ The perfective stem change has been analyzed as the combination of a verb root plus a perfective suffix in other Athapaskan languages (Kari 1979, Rice 1995, 2000), but this is not a transparent process in Dëne (Li 1946, Cook in preparation).

${ }^{3}$ Orthographic symbols used: $g h=[\gamma]$, th $=[\theta], s h=\left[\int\right], c h=\left[t \int\right], z h=[3], j$ $=[\mathrm{d} 3], \mathrm{C}^{\prime}=$ glottalized $\mathrm{C}, \mathrm{V}=$ nasal $\mathrm{V}, \mathrm{V}^{\prime}=$ high-toned $\mathrm{V}$.

Abbreviations used: assert $=$ assertive particle, $\mathrm{cl}=$ classifier, comp $=$ complementizer, $\mathrm{gd}=$ gender, $\mathrm{H}=$ high tone, $\mathrm{impf}=$ imperfective, $\mathrm{N}=$ nasal feature, perf $=$ perfective, $s=$ singular, th $=$ thematic (part of verb lexeme), $4=$ "fourth person" (a type of obviation). English translations are provided by the speakers, and are not edited.

${ }^{4}$ In addition, a condition that TSit(e) and T must be adjacent might have to be added to (30).

${ }^{5}$ I thank Daniel Büring for bringing this question to my attention, and Hotze Rullmann for discussion.

${ }^{6}$ Imagine a situation in which someone intentionally only prays three quarters of the Lord's Prayer.

${ }^{7}$ Another possible way of approaching the Dëne perfective paradox is to assume that 'finish' is ambiguous between a true completion and a stopping interpretation. There is in fact evidence that the corresponding Dëne verbs $\supset a-n a-\varnothing-t^{\prime} e$ and $>a-n a-1-d h e ̈ n$ are ambiguous in just this way (Bortolin 1998, Wilhelm 2002). Then perhaps the Dëne perfective does not necessarily entail event completion in the strict sense, but simply selects a "maximal" event, as explained above, which accounts for the incompatibility with 'still V-ing'.

${ }^{8}$ It is not quite resolved whether verbs of the 'sit down' group use the - or ne-in the perfective (and whether they use $\varnothing$ or $n e$ - in the imperfective). See Cook (in prep).

${ }^{9}$ The idea that the-may reduce to high tone $(\mathrm{H})$ or delete entirely, particularly if preceded by another conjunct prefix, is due to Cook (in prep.)

${ }^{10}$ It is an interesting question, but a question difficult to answer whether the absence of telicity causes the quasi-telic meaning of the perfective, or vice versa. 
${ }^{11}$ Imperfective (and/or atelic) situations signal simultaneity. For example:

(i)
tthidziné k'e hesjën
วú tsątsą́naze déttsér
yesterday impf-1s-sing comp phone perf-ring
'yesterday while I was singing the phone rang'

\section{References}

Bohnemeyer, J. \& M. Swift. 2001. Default Aspect. Paper presented at the "Perspectives on Aspect" conference, Utrecht.

Bortolin, L. 1998. Aspect and the Chipewyan Verb. M.A. Thesis, Calgary: University of Calgary.

Comrie, B. 1976. Aspect. Cambridge: Cambridge University Press.

Cook, E-D. In preparation. Dëne Sułiné Grammar.

Dahl, Ö. 1985. Tense and Aspect Systems. Oxford: Blackwell.

Demirdache, H. \& M. Uribe-Etxebarria. 2000. The Primitives of Temporal Relations. In Martin, R. et al (eds). Step by Step. Essays on Minimalist Syntax in Honor of Howard Lasnik. Cambridge, Mass: MIT Press. $157-86$.

Dowty, D.R. 1979. Word Meaning and Montague Grammar. Dordrecht: Reidel.

Giorgi, A. \& F. Pianesi. 1997. Tense and Aspect. From Semantics to Morphosyntax. Oxford: Oxford University Press.

Grice, H.P. 1975. Logic and Conversation. In P. Cole \& J.L. Morgan (eds.), Syntax and Semantics 3: Speech Acts. New York: Academic Press. 41-58.

Hopper, P. (ed.). 1982. Tense-Aspect: Between Semantics \& Pragmatics. Amsterdam: John Benjamins.

Kamp, H. \& C. Rohrer. 1983. Tense in Texts. In Bäuerle, R. et al (eds.), Meaning, Use, and Interpretation of Language. Berlin: Walter de Gruyter. 250-69.

Kari, J. 1975. The disjunct boundary in the Navajo and Tanaina verb prefix complexes. IJAL 41:330-45.

Klein, W. 1994. Time in Language. London: Routledge.

Kratzer, A. More Structural Analogies Between Pronouns and Tenses. In Strolovitch, D. \& A. Lawson. SALT VIII Proceedings. Ithaca,NY: Cornell University. 92-110.

Krifka, M. 1992. Thematic Relations as Links between Nominal Reference and Temporal Constitution. In Sag, I. \& A. Szabolcsi (eds.), Lexical Matters. Stanford: CSLI. 29-53.

Landman, F. 1992. The Progressive. Natural Language Semantics 1:1-32. Levinson, S.C. 1984. Pragmatics. Cambridge: Cambridge University Press. Li, F-K. 1946. Chipewyan. In Osgood, C. (ed.), Linguistic Structures of Native America. (Viking Fund Publications in Anthropology 6.) New York: Johnson Reprint Corporation. 398-423. 
Midgette, S. 1996. Lexical Aspect in Navajo: The Telic Property. In Jelinek, E. et al. (eds.), Athabaskan Language Studies: Essays in Honor of Robert W. Young. Albuquerque: University of New Mexico Press. 305-30.

Parsons, T. 1990. Events in the Semantics of English. Cambridge, Mass: MIT Press.

Partee, B. 1984. Nominal and temporal anaphora. Linguistics \& Philosophy 7:243-86.

Paul, H. 1959. Deutsche Grammatik(5th ed). Vol. 4. Halle: VEB Max Niemeyer Verlag.

Reichenbach, H. 1947. Elements of Symbolic Logic. London: Macmillan.

Rice, K. 2000. Morpheme Order and Semantic Scope. Cambridge: Cambridge University Press.

Smith, C. 1991. The Parameter of Aspect. Dordrecht: Kluwer.

Smith, C. 1996. Aspectual Categories in Navajo. IJAL 62:227-631.

ter Meulen, A. 1995. Representing Time in Natural Language. The Dynamic Interpretation of Tense and Aspect. Cambridge: MIT Press.

Vendler, Z. 1967. Linguistics in Philosophy. New York: Cornell University Press.

Verkuyl, H. 1972. On the Compositional Nature of the Aspects. Dordrecht: Reidel.

Wilhelm, A. 2002. Situation Type and Viewpoint Aspect, or: Telicity and Perfectivity, in Dëne Sưtiné (Chipewyan). Proceedings of WSCLA (Workshop on Structure and Constituency in the Languages of the Americas) 7. Vancouver: University of British Columbia Working Papers in Linguistics.

Wilhelm, A. In preparation. The grammatization of telicity and durativity. Ph.D. dissertation, University of Calgary. 